\title{
RFIDリーダの技術と課題
}

\section{The Subject and Technology of Radio Frequency Identification (RFID) Readers}

\author{
荒井雅行 ${ }^{\dagger}$ \\ Masayuki Arai
}

\section{Summany}

RFID の技術には, 人や物に付けて利用する非接触 IC カードや無線 IC タグと呼ばれる媒体と，それと電気的に 無線通信を行い情報のやり取りを行うリーダユニットが ある. また, 周波数帯に関しては, RFID を運用するアプ リケーションによって LF (Low Frequency) 帯, HF (High Frequency) 帯, UHF (Ultra High Frequency) 帯が用いら れている.ここでは, Suica ${ }^{\circledR}, \mathrm{PASMO}{ }^{\circledR}$ などで利用され ている HF 帯 $13.56 \mathrm{MHz}$ と, 今後普及が期待される UHF 帯 $950 \mathrm{MHz}$ について, 特にリーダ側の技術と課題につい て解説する。

\section{IGE woris}

RFID, 無線 IC タグ, 非接触 IC カード, リーダライタ

\section{1.まえがき}

RFID 技術は, 日本の過去 20 年を見ると，まず，周 波数 LF 帯による動物管理, FA (Factory Automation) 分野で応用されてきた，現在でも，パレット(Pallet) 管 理, 遊戯場関係ではスキー場のリフト券管理, ゲーム機 器等に多く使用されている.

$\mathrm{HF}$ 帯の $13.56 \mathrm{MHz}$ については, 1999 年にISO/ IEC-14443 TypeA 規格対応のプリペイドカードとして ICテレホンカードが登場し, 国際的にも普及している。

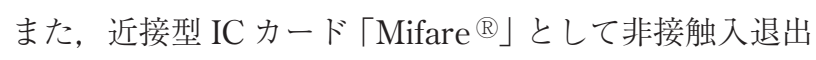
カード等にも使用され, 近年では成人識別としてタバコ 自動販売機に導入されたtaspo カードに利用されてい る. 更に, 2001 年には公共交通機関の自動改札機とし

\footnotetext{
†東京計器株式会社，東京都

Tokyo Keiki Inc., Tokyo, 144-8551 Japan
}

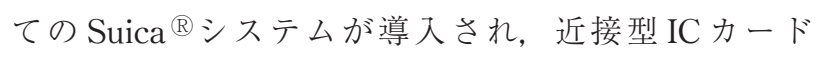

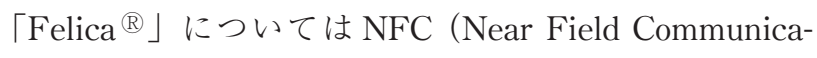
tion）規格として ISO (International Standard Organization）に提案され, 現在では ISO/IEC-18092 として規 格化されている.このほかの規格として, ISO/IEC14443 Type B 規格については, 住民基本台帳カードや パスポート, 免許証 ICカードなどに使用され, 国内外 の非接触 IC カードとして多く使用されている. 一方, 物品に貼り付け管理する無線 IC夕グとして ISO/ IEC-18000-3 Mode1 と同規格の近傍型規格のISO/ IEC-15693 があり, 多くは物流・流通管理の夕グとして 使用されている.

UHF 帯については, パッシブ型 (無電池)の $950 \mathrm{MHz}$ 带が，2005 年 4 月に電波法省令改正により 952 ～954 $\mathrm{MHz}$ での高出力型の無線 IC タグの利用が可能になっ た. 非営利法人の EPCglobal (RFID 国際標準化推進団 体）がISOに提案した「EPCglobal C1G2」規格が ISO/ IEC-18000-6C [1] として国際標準化されたことと, 夕 グ単価の低価格化と長距離一括読取り性能の向上によ り，UHF 帯 RFIDの普及が期待されている. 更に, 2008 年 5 月 29 日の電波法省令改正により, 低出力タイ プの $950 \mathrm{MHz}$ 帯アクティブ型も許可され, アクティブ 型無線 IC タグやセミアクティブ（またはセミパッシブ） 型として用途が広がっている. 一方で, $950 \mathrm{MHz}$ 帯近 傍磁界の磁界結合「Inductance coupling」で動作させる近 磁界型商品夕グ「Near Field Item Level Tag」も開発さ れており，その性能評価も今後期待される。

以上の RFID システムの概要について図 1 にまとめ る. 無線 IC タグには, 磁界で動作するものと電界で動作 するものに大別される. $125 \sim 135 \mathrm{kHz}$ 帯や $13.56 \mathrm{MHz}$ 帯はコイル同士の磁界結合で動作する電磁誘導方式であ り, $433 \mathrm{MHz}, 950 \mathrm{MHz}, 2.45 \mathrm{GHz}$ 帯は電界による電磁 波を利用して通信動作する電波方式が主流である. 


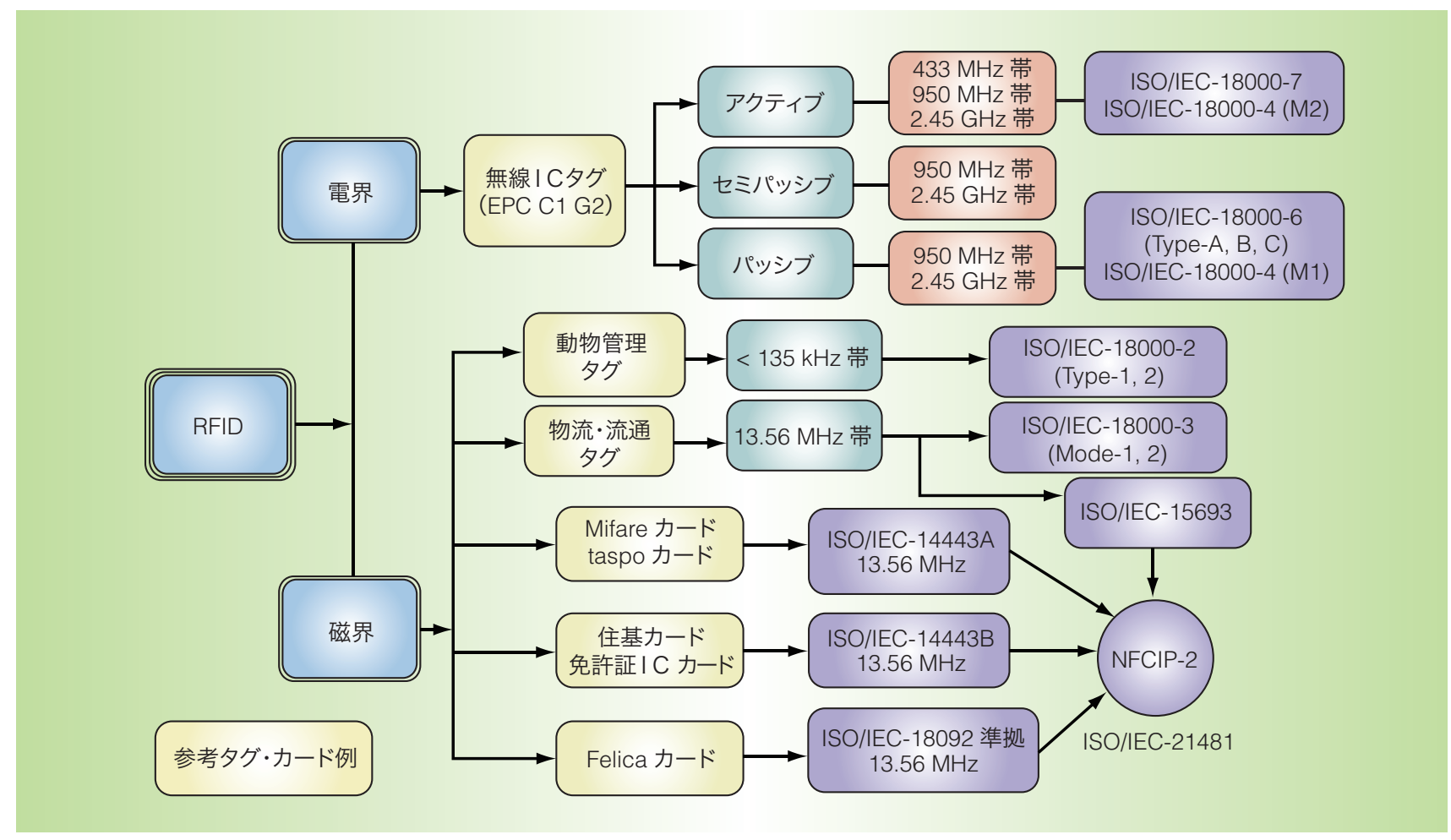

図 1 RFID システム概要

以上述べたように, HF 带 RFID の利用は, 既に 10 年 近く経ち, 現在, 専用端末からマルチリーダ端末として の利用に移行している。本論文では, ISO/IECの各種 規格に対応した HF 帯リーダのエアインタフェースの概 要及び通信動作について解説する。 また，今後利用拡大 が期待されるUHF 帯 RFID についても，その通信技術 と, リーダの送受信回路の概要, 構成について解説する. その中で, 干渉等の技術的問題に対する改善が期待され る共用化技術も含めた技術的課題についても解説する.

\section{HF 帯と UHF 帯の無線通信比較}

RFID では, HF 帯では電磁誘導によりタグとリーダ 間の通信を行う磁界通信方式, UHF 帯ではリーダから 電波を放射させ，電波を受信した夕グからの再放射を リーダで受信するバックスキャッタ方式が一般的に用い られている。本章では, これらの無線通信方式の違いに ついて説明する。

図 2 に HF 带磁界通信方式の動作原理を示す. HF 带 の波長から $\lambda / 2 \pi$ の距離を基点として近傍界と遠方界に 分類すると, 周波数 $13.56 \mathrm{MHz}$ は近傍界の磁界として 使用するループコイルを磁気的微小ダイポールに近似す るならば, 理論式の球座標表示の径方向成分の磁界強度 $H_{R}$ が近傍で支配的になり, 距離の 3 乗に反比例して減 衰する。この発生した磁界に真空中の透磁率 $\mu_{0}$ を掛け た磁束密度 $B$ に鎖交する無線 IC タグ等のコイルに, 電
磁誘導に関するファラデーの法則によって面積及び負荷 共振回路の $Q$, 巻数 $N$ に比例して二次電圧 $V_{2}$ が発生 する。このため, リーダコイルと無線 IC タグコイルの 二つの磁気的結合による相互誘導作用により互いにコイ ルに流れる電流が影響し合い, 通信を行うことができる. 電気回路のトランスコイルの等価回路に置き換えて算出 すると, 一次側の相互インダクタンス式からも分かるよ うに相互インダクタンス $=$ 結合係数の変化と二次側の負 荷変調 $Z_{2}$ の変化で受信電圧が変化する $[2] \sim[4]$.

この電磁誘導による方式はUHF 带でも利用可能であ る。その場合, 周波数に比例して二次側の電圧が発生す ることから, UHF 帯の周波数 $950 \mathrm{MHz}$ だと $13.56 \mathrm{MHz}$ に比較して, 単純計算で約 70 倍の効率が良いことにな る.しかし, $950 \mathrm{MHz}$ ではコイル (ループ) が波長に比 較して長くなるため, リーダ送信ループアンテナにヌル 点のない電流を均等に流すことが難しい [5]. 以上の点 から,リーダ回路構成やアンテナの容易性, コストの面 から見ればはるかに HF 带が勝る。が, 一方で, UHF 帯電磁誘導型の無線 IC 夕グの場合, 波長から 2 乗で減 衰する電界と 3 乗の磁界成分の両方の影響が, 効果的に 近傍で作用し, 金属や液体の影響の少ないUHF 带商品 タグとして機能するという点では, メリットが得られる 可能性もある.

図 3 にはUHF 带バックスキャッタ方式の動作原理を 示す。長距離リードが可能な遠方界で使用する UHF 带 無線 IC 夕グは, 距離の 1 乗で減衰する電界を利用する. 


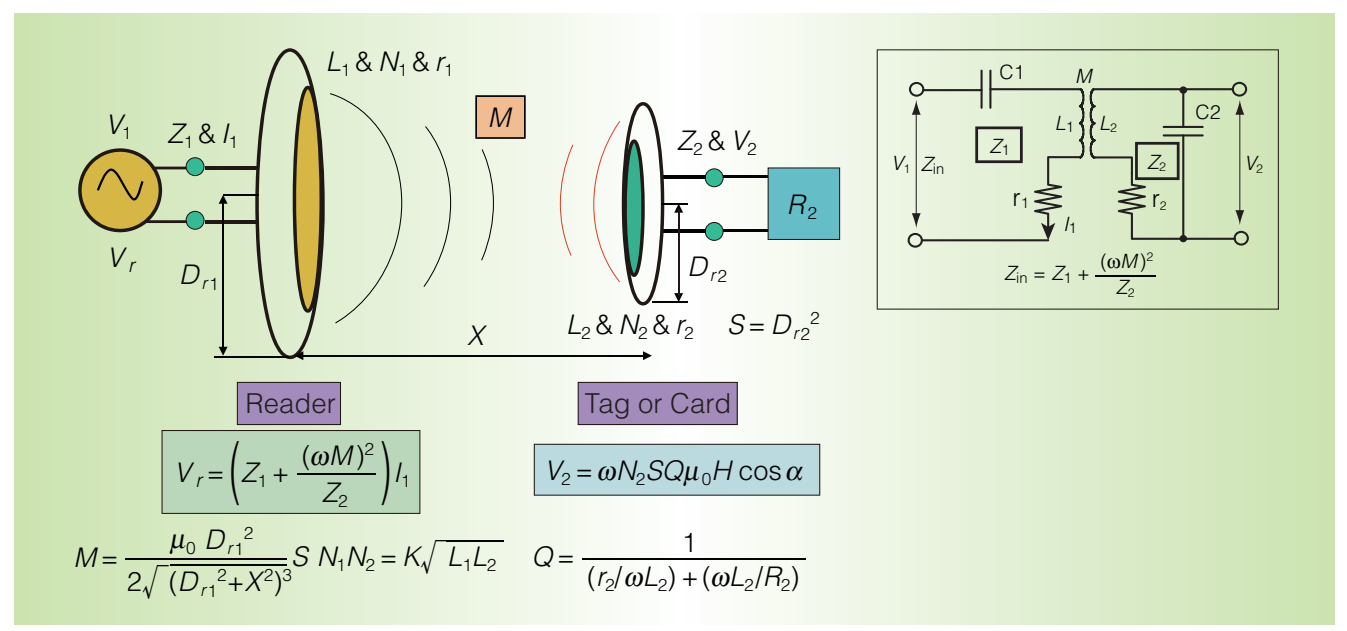

図 2 HF 帯磁界通信の動作原理

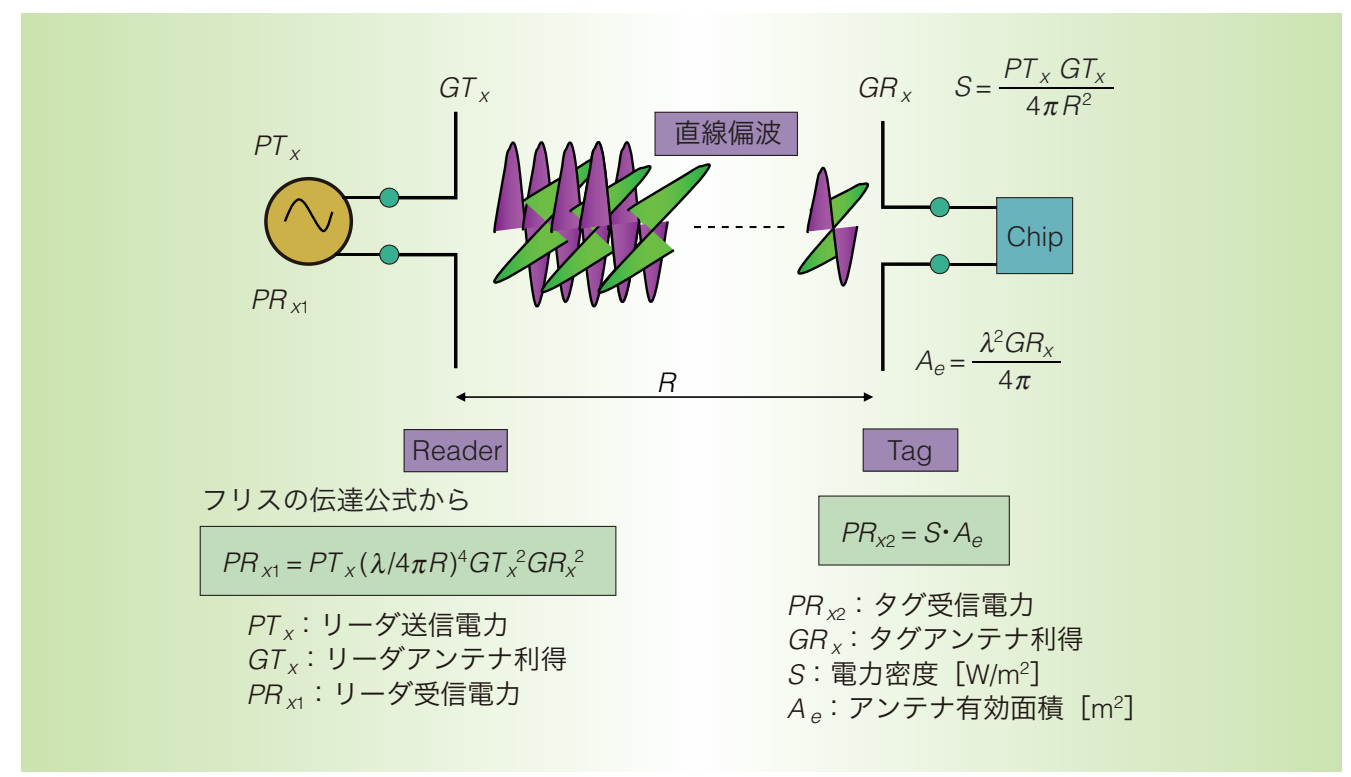

図 3 UHF 帯バックスキャッタ方式の動作原理

送信電力 $P T_{X}$ とアンテナゲイン $G T_{X}$ で送信した放射 電波は周辺の物体に反射しながら $(\lambda / 4 \pi R)^{2}$ の伝搬損( リスの伝達公式)で減衰し, タグアンテナに受信される。 無線 IC タグアンテナでは, アンテナの有効面積 $A e$ と 到達した距離 $R$ 点の電力密度 $S$ の積で受信電力 $P R_{X 2}$ が決まる。この受信電力は, アンテナと負荷の整合条件 によって負荷側に供給され，マッチング状態によって受 信電波が再反射する。この反射波の大きさは無線 IC 夕 グのアンテナと負荷のマッチングの善しあしで決まる. タグからの反射波が再度伝搬損で減衰してリーダ側の受 信回路に受信電力 $P R_{X 1}$ として到達する [6]， [4]．受信 電力 $P R_{X 1}$ には周辺の物体の静的反射や動的反射（移動 物体等)も含まれて抢り, その中に無線 IC タグのアンテ ナと負荷のマッチング，またはミスマッチングの制御で 振幅変調された反射波と一緒に受信される。

\section{HF 帯 RFID リーダの概要}

近年，非接触 ICカードに代表される自動改札機 $\left\lceil\right.$ Suica $\left.{ }^{\circledR}\right\rfloor\left\lceil\mathrm{PASMO}{ }^{\circledR} 」\right.$ や電子マネーなどで使用される $\left\lceil\mathrm{Edy}{ }^{\circledR} 」\right.$ カドが一躍脚光を浴びてきた。その背景には RFID の利便性が認識されたことがある。更に，同時に 多種多様な非接触 IC カードが存在し， 1 人数枚の非接 触 IC カードをもつ時代にもなってきている.

これらのカードには UID (Unique-Item Identification）という固有の識別子が存在している. UID 利用に はプライバシー問題やセキュリティの問題が発生する (UHF 带無線 IC タグも同様)。個人や物が知らないうち に無線 IC タグなどをもたされ，個人情報と関連付けが 行われたり，履歴情報として記録されることがあり，個 
人のプライバシーの侵害が発生する可能性がある。した がって, 本人の意思確認と同意が必要である [7]. セキュ リティ対策の方法としては, 非接触 IC カードや無線 IC タグのデータ暗号化として共通鍵暗号の DES（DataEncryption-Standard)，公開鍵暗号の RSA（RivestShamir-Adelman), 擬似乱数系列と排他的論理和をとっ たストリーム暗号などが使用されている $[8],[9]$.

\section{HF 帯 RFID リーダの技術}

この章では，一般的によく知られている，近接・近傍 規格の物理レイヤであるエアインタフェース技術と送受 信の復調について簡単に解説する。

\section{1 エアインタフェース}

表 1 に近接・近傍エアインタフェース規格を示す. 大 別して，近接型 (ISO/IEC-14443 規格)，ISO/IEC-18092 規格，近傍型（ISO/IEC-15693 規格）の 3 種類に分類さ れる。

近接型の ISO/IEC-14443 にはタイプ A とタイプ B が あり，物理的特性は ISO/IEC-14443-1, 電力伝送及び信 号インタフェースは ISO/IEC-14443-2，初期化及び衝突 防止は ISO/IEC-14443-3, 伝送プロトコルはISO/ IEC-14443-4 で規格化がされている[10]. タイプA と夕 イプ B の大きな違いは, タイプ A の場合, リーダから の送信を 100\%振幅変調「100 \%ASK (Amplitude Shift Keying)」で行い，符号化はモディファイドミラー符号 を使用，返信は副搬送波を使用し，ASK 負荷変調され たマンチェスタ符号が使われている。一方，夕イプ $\mathrm{B}$ は $10 \%$ 振幅変調で行い，符号化は NRZ（Non Return to Zero）符号が使われ。返信は副搬送波を使用し，BPSK （Binary Phase Shift Keying）負荷変調された NRZ 符号 が使われている。
ISO/IEC-18092 規格では，送信は $10 \%$ 振幅変調で行 い，符号化はマンチェス夕符号が使われている．特徴的 なのは, アクティブ動作での機器間通信が可能になって いる点である。

ここで, 変調方式と符号化方式について補足しておく. $100 \%$ 変調と $10 \%$ 変調の違いに関しては, タイプ A の場 合，非接触 IC カードまたは無線 ICタグチップ内で CPU (Central Processing Unit) を使用せず，ハードロ ジックで回路が設計されているため, $13.56 \mathrm{MHz}$ の搬送 波の $100 \%$ 変調落込みでも動作可能である. タイプ B の 場合，CPU 搭載で通信制御するため，CPU 用クロック の再生する $10 \%$ 変調が有利であり，スペクトル帯域が 広がらないなどの特長がある。符号化方式に関しては, NRZ 符号の場合，“1’や‘0’の連続が続いた場合には直流 信号成分が多くなるため復調が難しい. それに比較して, マンチェス夕符号は直流成分がないが，スペクトル带域 が広がってしまう。ミラー符号は両方の利点を持ち併せ ており，スペクトル带域が狭く電力伝送効率が良い。そ のミラー符号の立上りと立下りでパルス化した信号がモ ディファイドミラー符号である [11].

近傍型の ISO/IEC-15693 規格では，パルス位置変調 PPM (Pulse Position Moduration) 符号が用いられてい る。低速の場合には通信速度が遅いため, $13.56 \mathrm{MHz}$ の $\pm 7 \mathrm{kHz}$ 带域内に変調時の占有带域幅が収まり，電波法 の技術基準である電界強度スペクトルマスクのサイドバ ンドまで，ピークパワーを上げられる。これから，他の規 格に比較して無線 IC タグとの通信距離を伸ばせる [12].

図 4 に送信・受信信号の復調の流れを示す。一例とし て, Felicaカードで使用されている ISO/IEC-18092 準 拠のパッシブ通信を中心に説明する。

ISO/IEC-18092 は，双方向同じ通信フォーマットに なっており，通信速度も $212 \mathrm{kbit} / \mathrm{s}$ と同じである [13].

表 1 近接・近傍エアインタフェース規格

\begin{tabular}{|c|c|c|c|c|c|c|c|}
\hline & \multirow{2}{*}{\multicolumn{2}{|c|}{ 項 目 }} & \multicolumn{2}{|c|}{ ISO/IEC-14443 近接 } & \multirow{2}{*}{ ISO/IEC-18092 } & \multicolumn{2}{|c|}{ ISO/IEC-15693 近傍 } \\
\hline & & & \multirow{2}{*}{$\begin{array}{c}\text { タイプA } \\
13.56 \mathrm{MHz}\end{array}$} & \multirow{2}{*}{$\begin{array}{r}\text { タイプ B } \\
13.56 \mathrm{MHz}\end{array}$} & & 低速 & 高速 \\
\hline \multirow{5}{*}{ リーダーカード } & \multicolumn{2}{|c|}{ 搬送波周波数 } & & & $13.56 \mathrm{MHz}$ & $13.56 \mathrm{MHz}$ & $13.56 \mathrm{MHz}$ \\
\hline & \multicolumn{2}{|c|}{ 必要帯域幅 } & $\pm 339 \mathrm{kHz}$ & $\pm 106 \mathrm{kHz}$ & $\pm 424 \mathrm{kHz}$ & & \\
\hline & \multicolumn{2}{|c|}{ 変調方式 } & ASK100\% & ASK10\% & ASK10\% & ASK100\% & ASK10\% \\
\hline & \multicolumn{2}{|c|}{ 変 調 符 号 } & モデイファイドミラー & NRZ & マンチェスタ & PPM 1: 256 & PPM 1:4 \\
\hline & \multicolumn{2}{|c|}{ 通 信 速 度 } & $106 \mathrm{kbit} / \mathrm{s}$ & $106 \mathrm{kbit} / \mathrm{s}$ & $212 \mathrm{kbit} / \mathrm{s}$ & $1.65 \mathrm{kbit} / \mathrm{s}$ & $26.4 \mathrm{kbit} / \mathrm{s}$ \\
\hline \multirow{5}{*}{ カードーリーダ } & \multicolumn{2}{|c|}{ 変調方式 } & 負荷変調 & 負荷変調 & 負荷変調 & 負荷変調 & 負荷変調 \\
\hline & \multicolumn{2}{|c|}{ 通 信 速 度 } & $106 \mathrm{kbit} / \mathrm{s}$ & $106 \mathrm{kbit} / \mathrm{s}$ & $212 \mathrm{kbit} / \mathrm{s}$ & $6.62 \mathrm{kbit} / \mathrm{s}$ & $26.4 \mathrm{kbit} / \mathrm{s}$ \\
\hline & \multirow{3}{*}{ 副搬送波 } & 周 波 数 & $847.5 \mathrm{kHz}$ & $847.5 \mathrm{kHz}$ & & $\begin{array}{l}423.75 \mathrm{kHz} \\
484.28 \mathrm{kHz}\end{array}$ & $423 \mathrm{kHz}$ \\
\hline & & デイジ夕ル変調方式 & ASK & BPSK & ASK & FSK & ASK \\
\hline & & 符号化 & マンチェスタ & NRZ & マンチェスタ & マンチェス夕 & マンチェス夕 \\
\hline
\end{tabular}




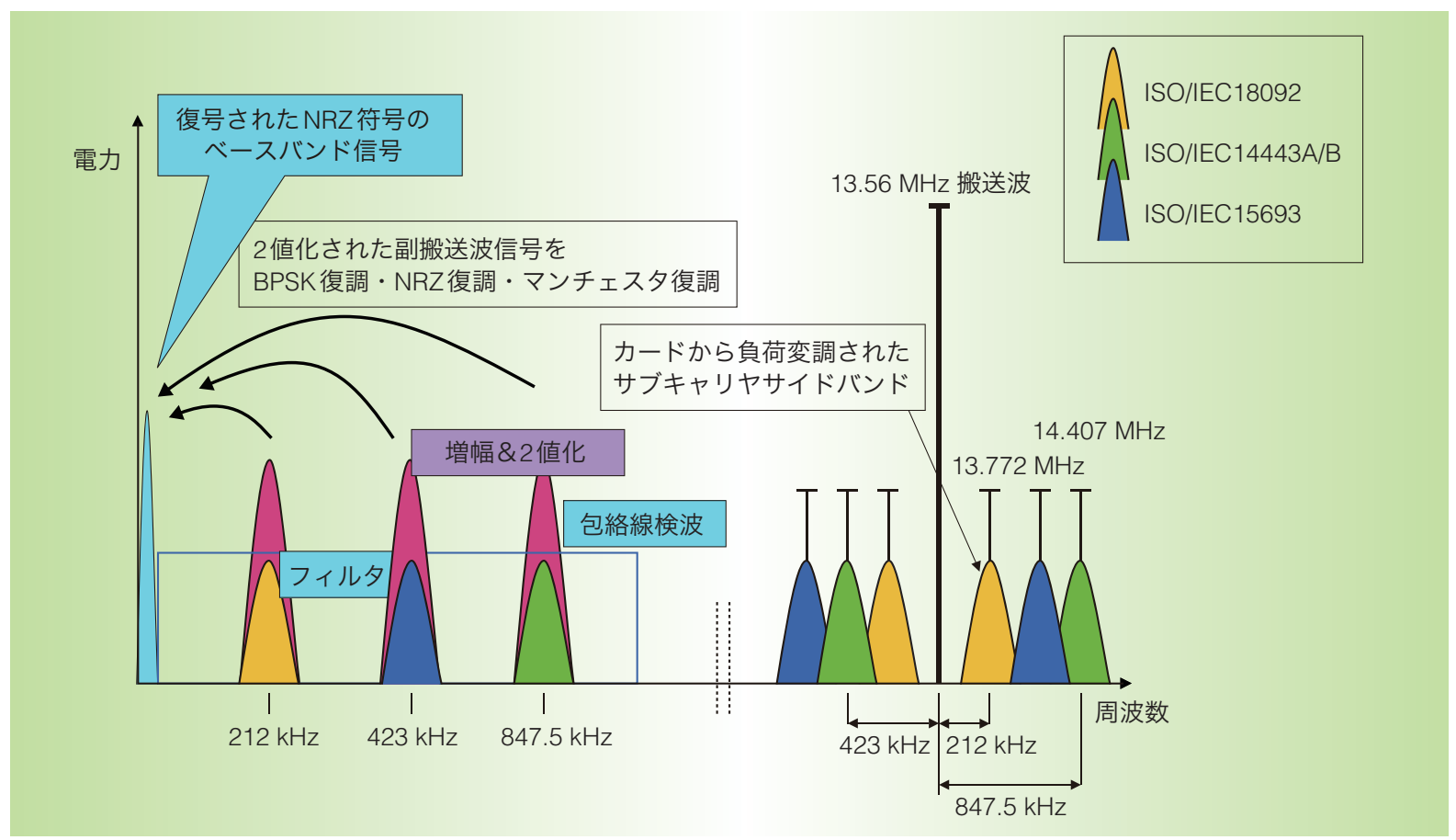

図 4 送信・受信信号の復調概念図

他の規格では，カードからの返信に副搬送波の $423 \mathrm{kHz}$ や $847.5 \mathrm{kHz}$ を使用し, 振幅変調または位相変調を行い, リーダ側で振幅変調または位相変調された信号を包落線 検波後，フィルタで $13.56 \mathrm{MHz}$ の搬送波を除去，増幅 し 2 值化する. 2 值化された NRZ またはマンチェス夕 符号の副搬送波信号からベースバンド信号の NRZ 符号 に復調する。

ISO/IEC-18092の場合，カードからの返信に副搬送 波を使用していないが, 基本的には他規格と同じ方法で 復調できる. カードからの負荷変調されたプリアンブル 付き振幅変調信号は包落線検波され， $\pi$ 型フィルタ数段 で搬送波を除去後, 増幅器で増幅してアナログからディ ジタルに 2 值化変換される. その信号をディジタル処理 回路に入力し，プリアンブル信号でクロック同期をとっ た後, $212 \mathrm{kHz}$ のクロックと排他的論理和をとりマン チェス夕符号から NRZ 符号に復号する. 同時に, 受信 データを巡回午長検査のCRC (Cyclic Redundancy Check）を行う. CRCデータのエラーチェック検出の方 法は, 15 段のレジス夕の初期值をゼロにして生成多項 式 $G(x)=X 16+X 12+X 5+1$ のタップで排他的論 理和をとったシフトレジスタ回路のループに受信データ を転送し, 剰余がゼロになれば受信データは正常と判断 する。

\section{UHF 帯 RFID リーダの概要}

図 5 にUHF 帯 RFID リーダの構成図を示す。ここで
は，一般的なスーパヘテロダイン方式の回路ではなく， 中間周波数でのイメージ周波数除去回路を必要とせずに 直接受信信号をベースバンド信号へ変換するダイレクト コンバージョン受信回路構成とした。 また，信号処理に は, DSP (Digital Signal Processor), DAC (Digital to Analog Converter), ADC (Analog to Digital Converter）等を使用したソフトウェア無線回路もある が，ここでは安価な CPUとハード的に自由度のある FPGAの構成にした。

内部構成は 4 ブロックに分かれ, 高周波送信部, 高周 波受信部, 信号処理の FPGA 部, プロトコル処理の $\mathrm{CPU}$ 部がある. 高周波送信部は, 周波数シンセサイザ, Driver 増幅器, 二重平衡変調器のDBM (Double Balanced Mixer), 表面波弾性素子のSAW (Surface Acoustic Wave) フィルタ, 電力増幅器で構成される. 高周波受信部は, 低雑音増幅器 LNA（low noise amplifier), IQ (Inphase/Quadrature) 復調器, LPF (Low Pass Filter) 低域フィルタ, 低周波増幅器, コンパレー 夕による 2 值化回路で構成される. LBT (Listen Before Talk）のキャリヤセンス機能も同じ受信回路で带域フィ ル夕帯域及びゲインを変えることで構成される. FPGA 回路は送信信号の NRZ 符号から PIE (Pulse Interval Encoding）符号に変換する回路とプリアンブル信号の生 成回路及び $\mathrm{CRC}$ 生成回路で構成され，また受信回路で は受信信号のFM0（bi-phase space）符号や Millersubcarrier 符号の復調及び CRCチェック回路, 送受信 バッファ回路で構成される。 CPU 回路はプロトコル制 


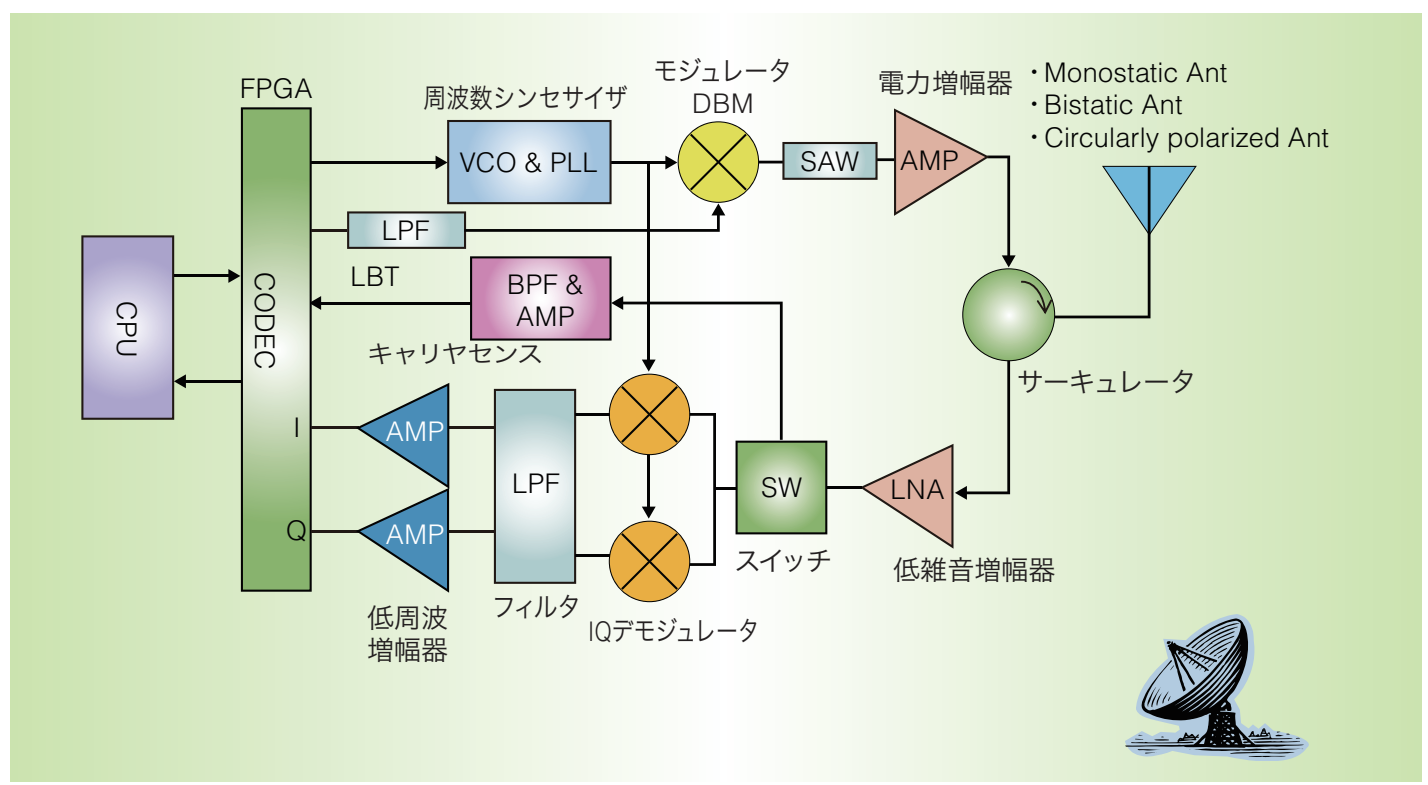

図 $5 \mathrm{UHF}$ 帯 RFID リーダの構成図

表 $2 \mathrm{UHF}$ 帯エアインタフェース規格

\begin{tabular}{|c|c|c|c|c|}
\hline \multicolumn{2}{|c|}{ 項 目 } & ISO/IEC-18000-6A & ISO/IEC-18000-6B & ISO/IEC-18000-6C \\
\hline \multirow{5}{*}{ リーダータグ } & 搬送波周波数 & $860 \sim 960 \mathrm{MHz}$ & $860 \sim 960 \mathrm{MHz}$ & $860 \sim 960 \mathrm{MHz}$ \\
\hline & 変 調 度 & $27 \sim 100 \%$ & $18 \%$ or $100 \%$ & $80 \sim 100 \%$ \\
\hline & 変調方式 & DSB-ASK $\cdot$ SSB-ASK & DSB-ASK $\cdot$ SSB-ASK & $\begin{array}{l}\text { DSB-ASK } \cdot \text { SSB-ASK } \\
\text { or PR-ASK }\end{array}$ \\
\hline & 変調 符 号 & PIE & マンチェスタ & PIE \\
\hline & 通信速度 & $33 \mathrm{kbit} / \mathrm{s}$ & 10 or $40 \mathrm{kbit} / \mathrm{s}$ & $26.7 \sim 128 \mathrm{kbit} / \mathrm{s}$ \\
\hline \multirow{4}{*}{ タグーリーダ } & 変調方式 & ASK & ASK & ASK or PSK \\
\hline & 通信速度 & $40 \mathrm{kbit} / \mathrm{s}$ & $40 \mathrm{kbit} / \mathrm{s}$ & $\begin{aligned} 40 & \sim 640 \mathrm{kbit} / \mathrm{s} \quad(\mathrm{FM} 0) \\
5 & \sim 320 \mathrm{kbit} / \mathrm{s} \quad(\mathrm{Msub})\end{aligned}$ \\
\hline & 衝突防止方式 & Aloha & Binary Tree & Slotted Random \\
\hline & 符 号 化 & FM0 & FM0 & FM0 or Miller subcarrier \\
\hline
\end{tabular}

PIE (Pulse Interval Encoding)：パルス間隔エンコーダ, FM0（bi-phase space）：バイフェーズスペース符号, Miller subcarrier：ミラーサブキャリヤ符号, DSB (Double Side Band)-ASK : 両側波帯振幅変調, PR (Phase Reversed)-ASK : 位相反転振幅変調

御と通信制御回路のソフトウェア処理を行う.

表 2 に, ISO/IEC-18000 規格の UHF 带エアインタ フェース規格を示す。次に，表 2 の規格 (ISO/IEC18000-6C）において，日本の電波法に則した UHF 帯 RFID リーダの具現化する上で必要なエアインタフェー ス技術に関して解説する。

\section{1 ハードウェア (送信回路)}

送信部では電波法で定めた技術基準である諸規定值を 満足するように設計しなければならない。技術基準適合 の取得と高出力型の場合，構内無線局の免許登録が必要 である。中でも带域内及び帯域外のスプリアス発射の強 度の許容值が厳しい.

図 6 に日本の電波法の不要ふく射規定を示す。また,
図 7 に帯域内のチャネルスペクトルマスクと ISO/IEC18000-6C 規格の Dense Reader Mode（干渉抑圧リーダ モード)スペクトルマスクを示す。

干渉に強い Dense Reader Modeでは，変調時に両側 波帯スペクトルの広がりが応答信号に影響しないように スペクトル带域をシンボル時間（Tari）によって制限し,

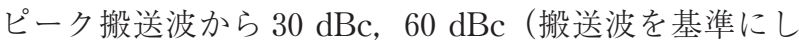
た $\mathrm{dB}$ ）の減衰を規定している(赤線)。日本では，100 $\mathrm{kHz}$ 帯域で, $-10 \mathrm{dBm} / 100 \mathrm{kHz},-29 \mathrm{dBm} / 100 \mathrm{kHz}$ の減衰を規定している。日本の電波法では带域外に携带 電話の带域があるため厳しい制限值であるが，干渉抑圧 が必要な Dense Reader Modeでは，更に厳しい帯域制 限が必要とされる。帯域内でもう一つ厳しい制限として, 


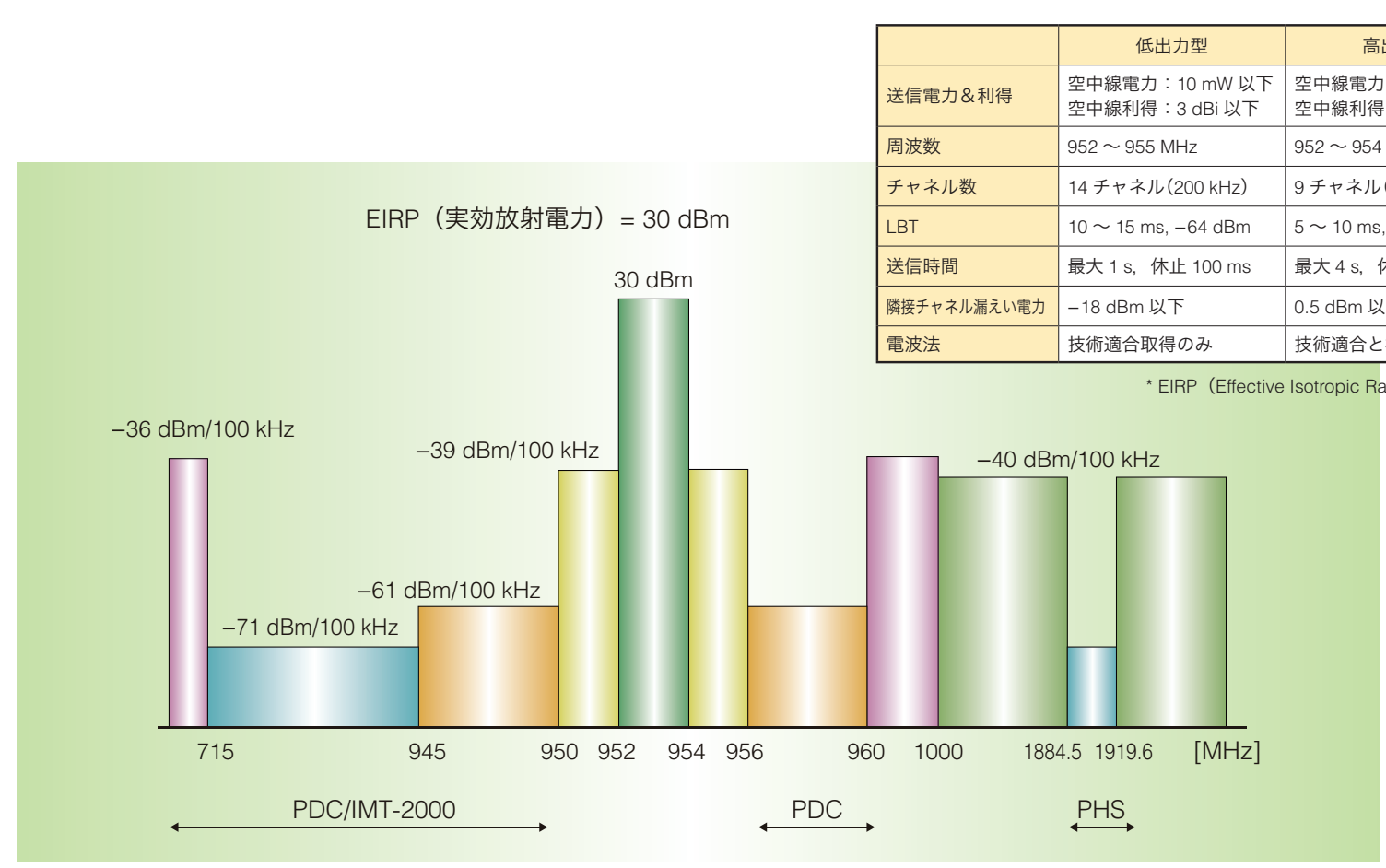

図 6 電波法の不要ふく射規定

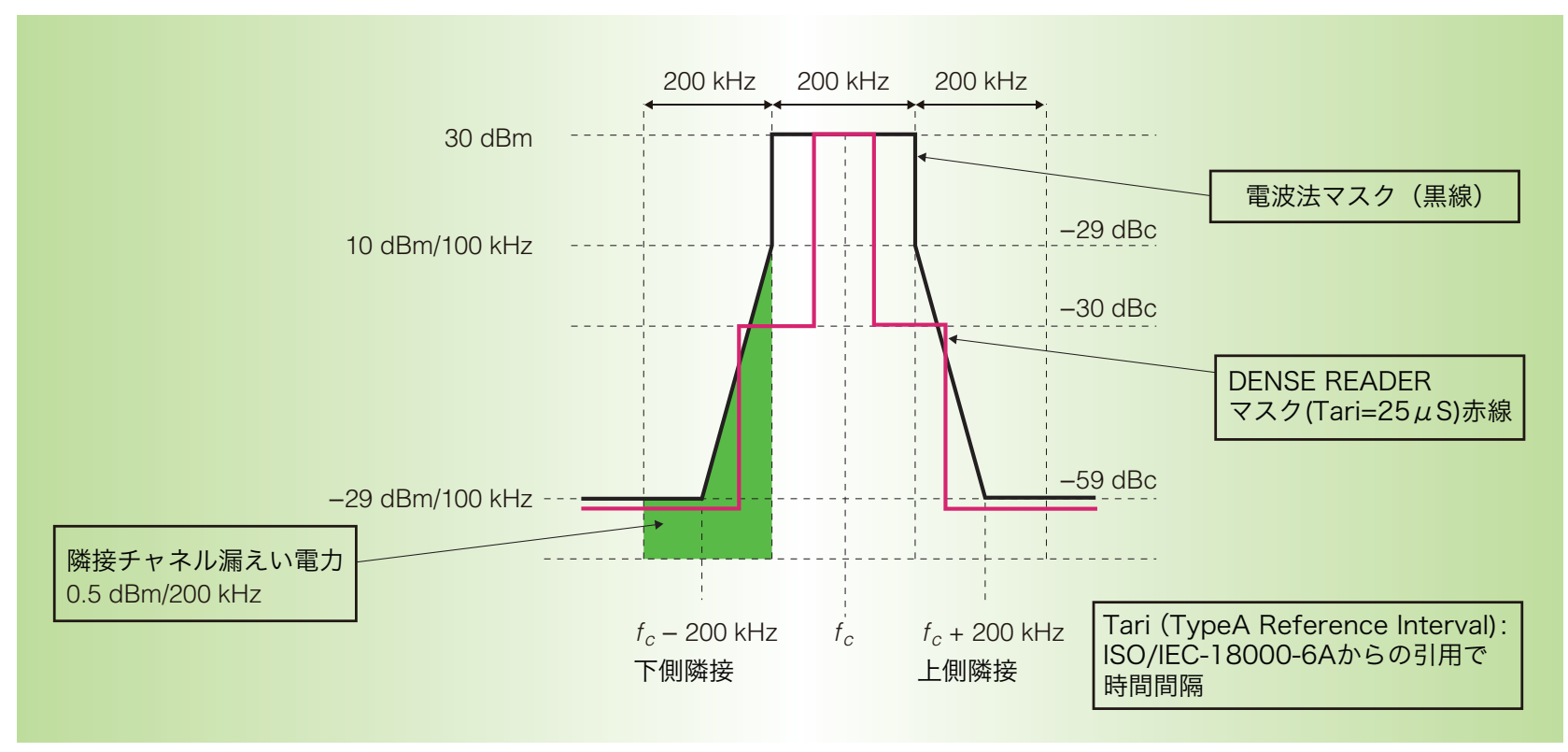

図 7 チャネルスペクトルマスク

$952 \mathrm{MHz}$ の最初のチャネルのスペクトル帯域のすそが - $39 \mathrm{dBm} / 200 \mathrm{kHz}$ にかからないように带域制限する必 要がある.よって, この带域ではピークから $69 \mathrm{dBc} の$ 減衰が必要である。また, 隣接チャネル漏えい電力の規 定もあり，規定值の $0.5 \mathrm{dBm} / 200 \mathrm{kHz}$ (緑線) を超えな いようにしなければならない[14].

帯域外ではパワーアンプの手前には急しゅんな帯域 フィルタ BPF (Band Pass Filter) の SAW フィルタを 入れ, 後段に誘電体フィルタで規定值まで減衰させる.
2 倍の高調波の $1884.5 \mathrm{MHz}$ 超え 1919.6 MHz 以下で - $61 \mathrm{dBm} / 1 \mathrm{MHz}$ の減衰が必要なため, 高次のフィル 夕が必要である。

規格上の転送速度は送信側で $40 \mathrm{kbit} / \mathrm{s}$ から $160 \mathrm{kbit} / \mathrm{s}$ まで使用可能のため, それぞれの転送速度に対して帯域 制限フィルタが必要になる, ロールオフフィルタを用意 する方法として, アナログで処理する場合, 高次のフィ ルタが必要になり, フィルタ段数を増やして組み合わせ るか, または DSP 等でディジタルフィルタによるソフ 
卜処理で可変にする必要がある $[15],[16]$.

\section{2 ハードウェア (受信回路)}

FM0 受信と Miller subcarrier 受信の基本的な通信動 作を簡単に解説する. 図 8 に FM0 受信動作のスペクト ル概念図と図 9 に Miller subcarrier 受信動作のスペク トル概念図を示す。

FM0 受信では送信パワースペクトルの带域内にかぶ さるように無線 IC タグからの応答信号が各チャネルで 返信される，同じチャネルが重なると無線 IC タグから の信号が妨害され受信できないため, LBT (Listen Before Talk）の機能により送信チャネルが別のリーダ の送信チャネルと同じにならないようにする。具体的に は, 送信前に, 送信したいチャネルの電力を受信回路で $-74 \mathrm{dBm}$ 以下かをチェックし, 以下であれば送信し, 使用中であれば別チャネルで送信するなどの衝突を避け るように制御する。

無線 IC タグから返信 FM0 信号（40 kbit/s）は低雑音 増幅器で増幅後, IQ (Inphase/Quadrature) 復調器のミ クサで同じ搬送波周波数と掛け算され，位相 90 度差の 二つの微小ベースバンド信号が DC (Direct Current) 近 傍で復調される。 その直流 DC 近傍周波数に復調された 微小信号は带域フィルタで隣接チャネルなどの $200 \mathrm{kHz}$ 及び $400 \mathrm{kHz}$ 干渉ビート信号や DC オフセットなど除 去され低周波増幅器で増幅後, 論理信号に 2 值化されて 受信 FM0 信号から NRZ符号に復調される.

図 9 の Miller subcarrier 受信では, 無線 IC タグの応 答信号をサブキャリヤ周波数である LF 周波数(ここで は $200 \mathrm{kHz}$ ) まで離調させ, 送信スペクトルから隣接チャ ネルの带域へ応答信号を周波数変位させることで, 送信
スペクトルと衝突が起こらないようにする.チャネル 1 とチャネル 3 は応答チャネル専用とし, チャネル 2 は LBT なしの送信チャネルとするなど, 現状では使用で きないが, 今後, 電波法が改正される予定がある。また, Miller subcarrier 受信では周辺の複数リーダが送信チャ ネルとして応答専用チャネルを使用しないなどの工夫も 必要である。

受信した Miller subcarrier 信号は $200 \mathrm{kHz}$ のサブ キャリヤ周波数に落とされ, 低雑音増幅器で増幅後, IQ (Inphase/Quadrature) 復調器のミクサで同じ搬送波と 掛け算され位相 90 度差の二つの微小 $200 \mathrm{kHz}$ 受信信号 に復調される。隣接チャネルのチャネル 4,5 の 400 $\mathrm{kHz}$ 以上のビート信号はフィルタで除去され, DCオフ セット除去後, 増幅され論理信号に 2 值化され, 50 kbit/s の Miller subcarrier 信号から NRZ 符号に復調さ れる. $I$ (同相成分) と $Q$ (直交成分) の位相差 90 度の受 信信号が必要な理由は, 電波伝搬では, マルチパスのよ うに大地に反射した信号と直接波の信号が受信端で 90 度の位相差で一致した場合, 合成された受信信号はキャン セルされ出力されない. 同じように無線 IC タグの位置 が $1 / 4 \lambda$ の位相差で受信された場合, 出力が現れない又 ル点(不感带) となる。無線 IC タグを移動すると $1 / 8 \lambda$ 距 離ごとにヌル点を繰り返すため, $I$ と $Q$ の位相差信号の 絶対值をとりヌル点が発生しないように改善する.

このようにすることで, FM0 受信の場合では送信待 ちなどでリアルタイム性の確保が難しかったが, Miller subcarrier 受信ではLBT 不要送信チャネルにより改善 され，また応答専用チャネルにより受信妨害を避けるこ とができるため, 効率良く, 多くの夕グを一括受信できる.

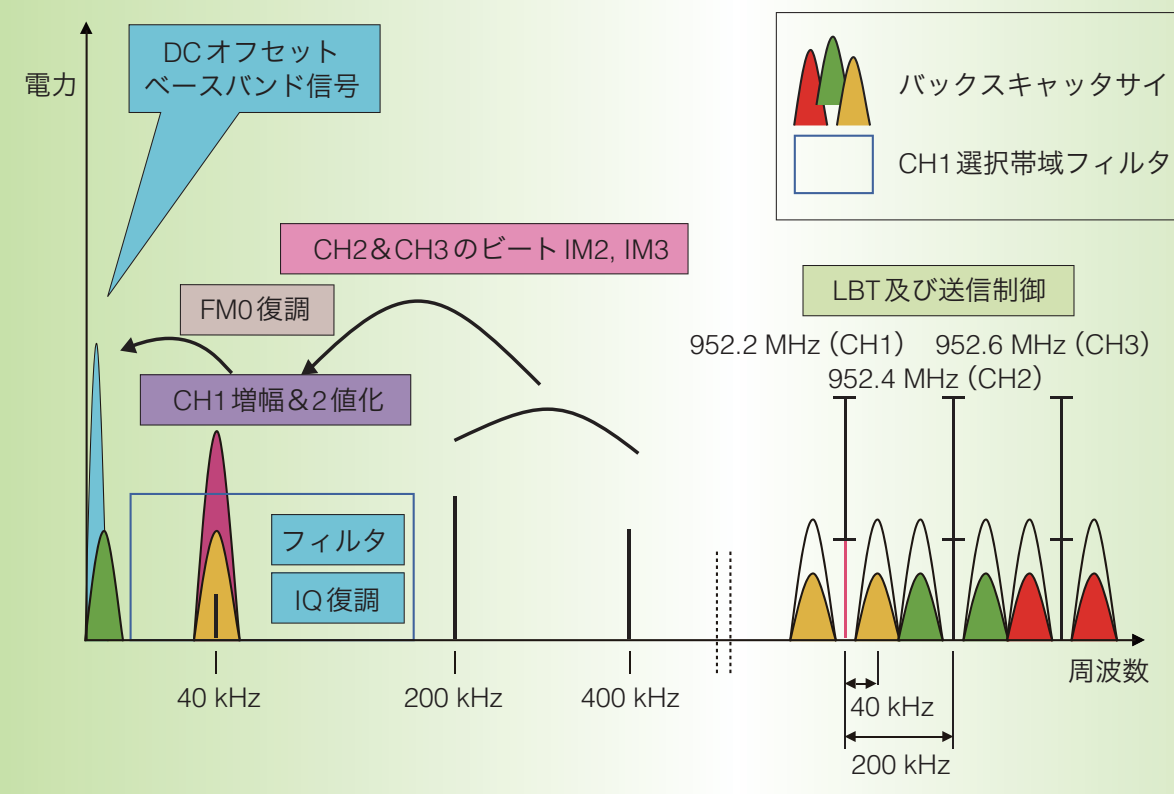

図 8 FM0 受信動作のスペクトル概念図 

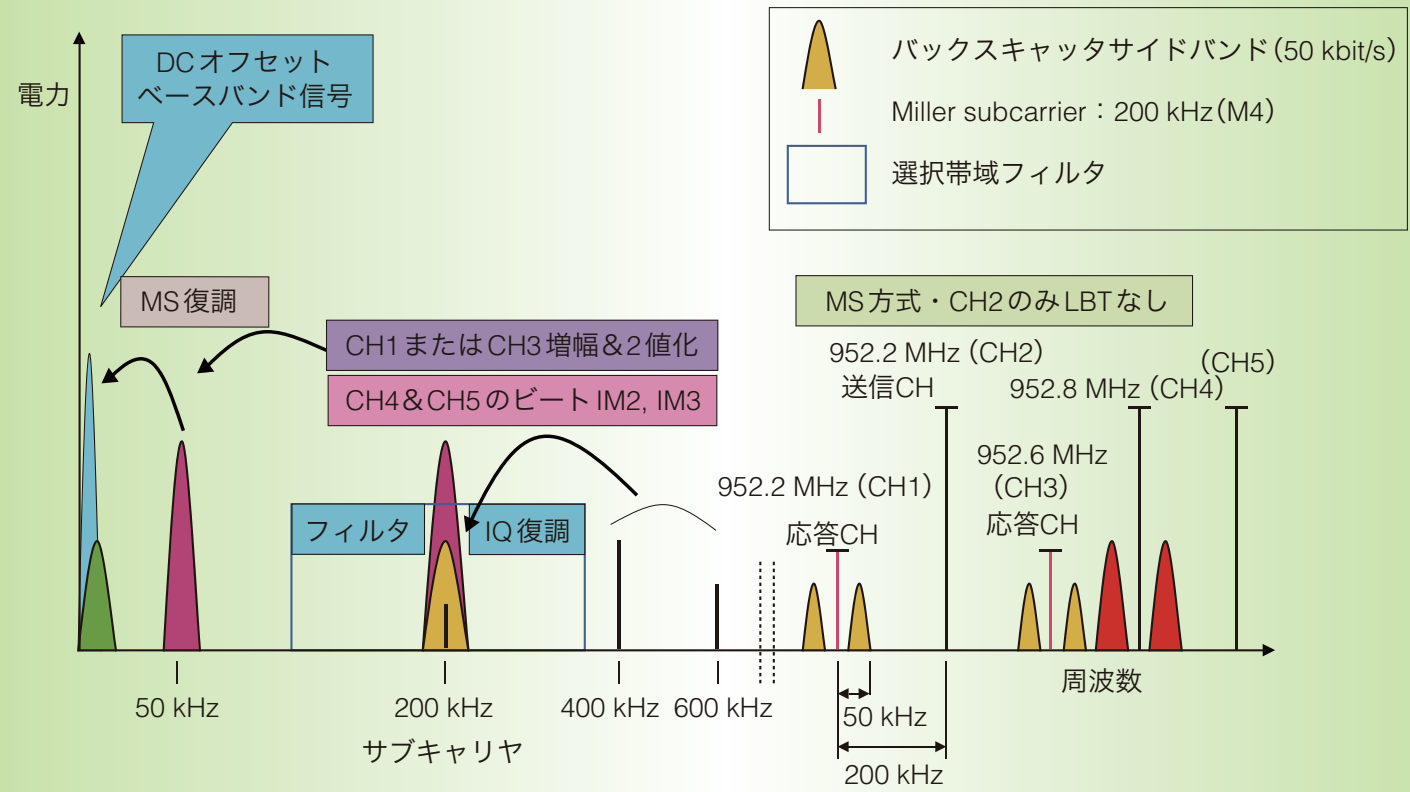

図 9 Miller subcarrier 受信動作のスペクトル概念図

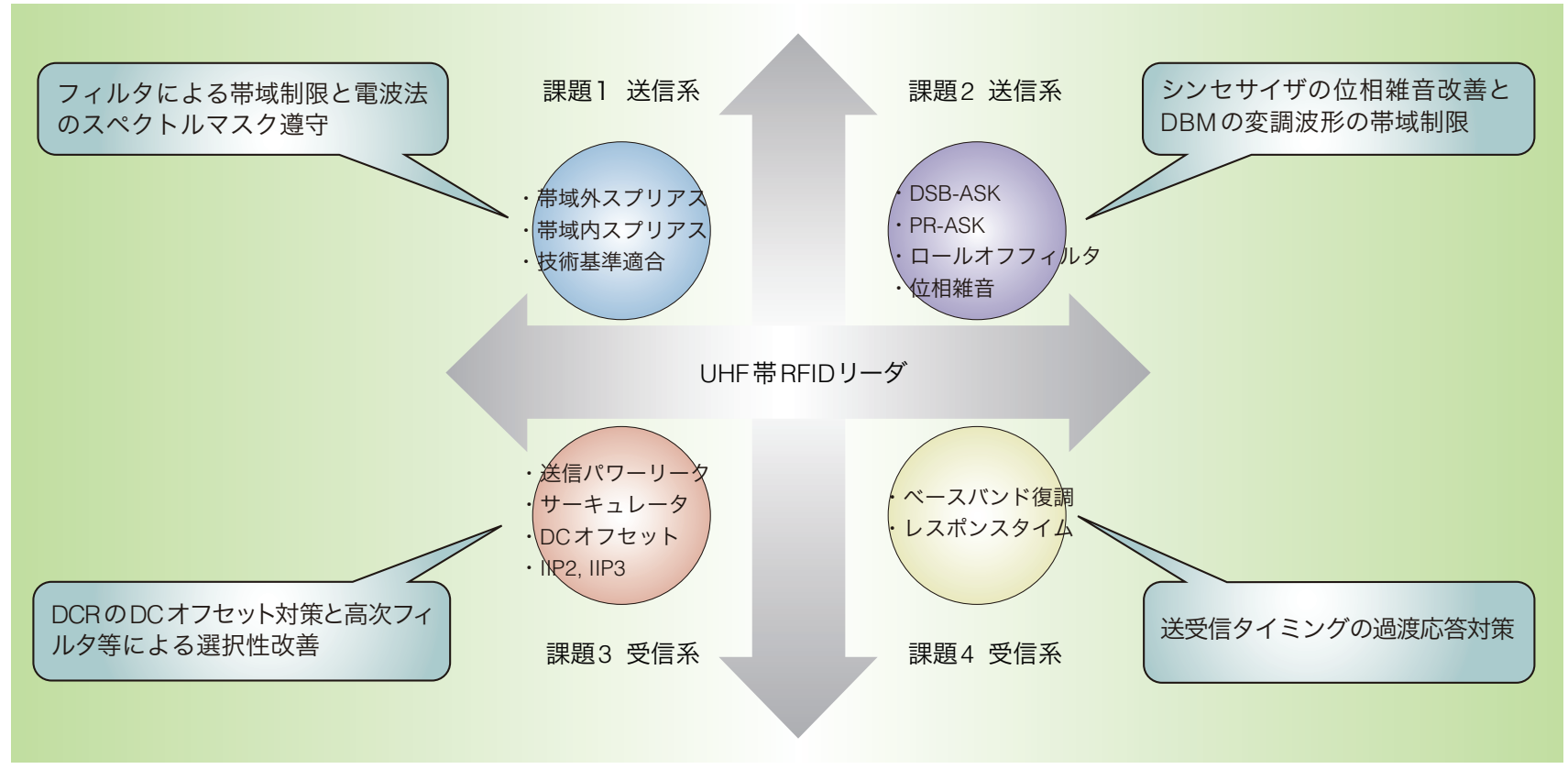

图 10 UHF 帯 RFID リーダの技術的課題

受信回路の課題としては, 復調時にダイレクトコン バージョン受信回路特有の直流近傍の DC オフセットと 増幅器のレスポンス特性で注意が必要であり, 直流カッ トのコンデンサ挿入，フィードバック AGC 回路など DCオフセットのキャンセル回路を必要となる [17]. また，相互変調ひずみの IIP3 (Input Third-order Intercept point) と IIP2 (Input Second-order Intercept point）に注意が必要である。受信回路のトータルの IIP3 や IIP2 が低いと受信ベースバンド信号にひずみが発生 し復調時のビットエラーを悪化させる原因になる。

\section{RFID リーダの課題}

これらの技術的事柄を踏まえて，RFIDリーダの課題 について解説する。図 10 に, 高周波回路設計で考慮す べきUHF 帯 RFID リーダの技術的課題をまとめた。こ れらの送受信アナログ回路技術の課題も, アナログ・ディ ジタル処理一体の半導体チップ化により性能向上が図ら れている. その他の技術的課題として, HF 帯 RFIDリー ダでは，シングルリーダが一般的に使用されているが, 
各種規格ごとに機器が違うなど煩雑であった。 カード等 に依存しない共通端末としてマルチリーダ化が期待さ れ，その一つにNFCIP-2 (Near Field Communication) 規格対応がある. UHF 帯のリーダ間干渉やタグコン フュージョンなどの問題は, LBT, Miller subcarrier 受信やリーダ送受信同期技術, 送信パワー\& 時間制御, 電波吸収体による遮へいなど対策が既に行われている. また，社会的課題である電磁波防護の安全指針と植込み 型医療機器へ及ぼす影響は，解決に時間がかかると思わ れる [18]，[19]。プライバシー問題やセキュリティの問 題もタグの普及により表面化してくる問題であり, 時間 のかかる課題である.

\section{7. むす び}

$\mathrm{HF}$ 带近接・近傍型の ISO/IEC-14443AB ・ ISO/ IEC-18092 及び ISO/IEC-15693の各規格の物理レイヤ であるエアインタフェースに関して解説した。また, UHF 带 RFID リーダの高周波回路の技術と課題につい ても, 多少詳細に解説し, 現状の RFID リーダの技術を 紹介した。今回，紹介できなかったが，RFIDリーダ アンテナ技術や RFID リーダ信号処理技術について，今 後，機会があれば紹介したい。干涉問題を含めた技術的 条件等の規定改正はこれからであり，社会的課題の医療 機器問題などシステム運用を含めた改善が総務省（電波 法)及び業界全体で行われていくと考える.

今後, 無線 IC 夕グ・非接触 IC カードの利便性認知や タグ単価の低価格化などにより, HF 带・UHF 带 RFID 全体の需要が, 増加することを期待したい.

\section{文献}

[1] EPCglobal, EPC Radio-Frequency Identity Protocols Class-1 Generation-2 UHF RFID Protocol for Communications at $860 \mathrm{MHz}-960 \mathrm{MHz}$, Version 1.1.0, 2005.

[2] 後藤憲一, 山崎修一郎, 電磁気学演習, 共立出版, 1994.

[3] 古谷恒雄, 空中線及び電波伝搬, 啓学出版, 1971.

[4] T. A. Scharfeld, "An analysis of the fundamental constraints on low cost passive radio-frequency identification system design," Northwestern University at the Massachusettts Institute of Technology, pp.22-36, Aug. 2001.

[5] D. M. Dobkin, S. M. Weigand, and N. lye, "Segmented magnetic antennas for near-field UHF RFID," Microw. J., vol.50, no.6, June 2007.

http://www.mwjournal.com/Journal/article.as p?HH_ID=AR_4597

[6] K. Finkenzeller, Fundamentals and Applications in Contactless Smart Cards and Identification, Second ed., RFID Handbook, 2006.

[7] 高木浩光, “RFID のプライバシ一問題とその解決策,”産業 技術総合研究所, 情報セキュリティ研究センター, 2006.

[8] American Public Transit Association, Universal Transit Fare card Standards (UTFS), "Trendsin electronic fare media technology," Version 1.40, Dec. 2003.

[9] Mifare (In) Security Update January 2008 By Dr David
Everett, CEO, Smart Card Group. http://www.smartcard.co.uk/mifare.html

[10] ISO/IEC FCD 14443-3, Identification cards contactless integrated circuit (s) cards proximity cards Part 3 : Initialization and anticollision, 1999.

[11] M. Hecht and A. Guida, "Delay Modulation," Proc. IEEE, pp.1314-1316, July 1969

[12] ISO/IEC18000, Part3, Information Technology AIDC, Techniques-RFID, for Item, Management-Air-Interface, Part-3 Parameters for air interface communications at $13.56 \mathrm{MHz}, 2002$.

[13] Standard, ECMA-340, Second Edition/Dec. 2004. Near Field Communication Interface and Protocol (NFCIP-1).

[14）テレコムエンジニアリングセンター, “950MHz 帯移動体識 別の特性試験方法,”2006.

[15］河合武宏, “ソフトウエア無線による RFID リーダライタの 開 発,” OMRON TECHNICS, vol.47, no.2, pp. 75-79, 2006.

[16］ 三次 仁,“電子夕グにおける電力と信号の伝送,”2006 信 学総大, CBS-1-1, March 2006.

［17］田中 聡, “半導体集積化受信機の基礎,”日立製作所中央研 究所, 2005.

［18］総務省情報通信審議会，“情報通信技術分科小電力無線シス テム委員会報告,”Dec. 2007.

[19］流通システム開発センター, “RFID 技術動向運用環境調査報 告書,” March 2008.

(平成 20 年 5 月 7 日受付, 8 月 18 日再受付)

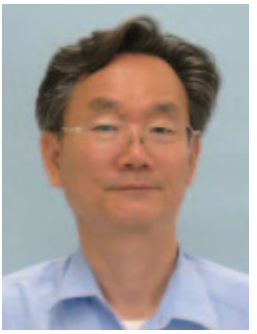

荒井 雅行 (正員)

昭 53 電機大・工・電子卒. 昭 46 (株) 東 京計器入社. 現在, LF 帯・HF 帯 RFID リー ダ開発, UHF 帯 RFID $950 \mathrm{MHz}$ リーダの 研究開発を経て．陸上 1 級・2 級無線技術 士・電気通信主任技術者・工事担任者とし て有線電気通信及び無線通信機器開発に従 事. 自動認識基本技術者(JAISA 会員). 